\title{
PENINGKATAN KEAKTIFAN DAN HASIL BELAJAR KIMIA SISWA MELALUI STRATEGI PEMBELAJARAN THINK-TALK-WRITE DI KELAS X SMA PGRI INDRALAYA
}

\author{
Etrie Jayanti \\ Universitas Islam Negeri Raden Fatah Palembang \\ E-mail: etriejayanti_uin@radenfatah.ac.id
}

\begin{abstract}
Abstrak: Penelitian yang berjudul "Peningkatan Keaktifan dan Hasil Belajar Kimia Siswa Melalui Strategi Pembelajaran Think-Talk-Write di Kelas X SMA PGRI Indralaya" ini bertujuan untuk untuk mengetahui secara empiris ada tidaknya peningkataan keaktifan dan hasil belajar siswa di kelas X SMA PGRI Indralaya melalui penerapan strategi pembelajaran think-talk-write. Metode yang digunakan dalam penelitian ini adalah penelitian tindakan kelas. Penelitian ini dilakukan dalam tiga siklus, dalam satu siklus terdapat dua kali pertemuan. Teknik pengumpulan data menggunakan lembar observasi dan tes akhir siklus. Hasil penelitian menunjukan rata-rata keaktifan pada siklus I sebesar 50,56\%, pada siklus II sebesar 64,66\%, pada siklus III sebesar $82,50 \%$. Rata-rata hasil belajar siswa sebelum dilakukan tindakan $\left(\mathrm{T}_{0}\right)$ yaitu 54,26\% dengan ketuntasan klasikal sebesar 34,78\%, rata-rata hasil belajar siklus I $\left(\mathrm{T}_{1}\right)$ yaitu 59,48 dengan ketuntasan klasikal sebesar 52,17\%, rata-rata hasil belajar siklus II $\left(\mathrm{T}_{2}\right)$ yaitu 67,62 dengan ketuntasan klasikal sebesar $66,67 \%$ dan rata-rata hasil belajar pada siklus III $\left(\mathrm{T}_{3}\right)$ yaitu 75,08 dengan ketuntasan klasikal sebesar $86,95 \%$. Hasil penelitian menunjukkan bahwa penerapan strategi pembelajaran think-talk-write dapat meningkatkan keaktifan dan hasil belajar kimia siswa. Peneliti memberikan saran kepada guru, sekolah, dan peneliti lain dapat menerapkan strategi pembelajaran think-talk-write di kelas sebagai salah satu alternatif untuk meningkatkan hasil belajar siswa.
\end{abstract}

Kata kunci : hasil belajar, keaktifan, penelitian tindakan kelas, think-talk-write

\section{PENDAHULUAN}

Pendidikan merupakan sebuah program yang terdiri dari beberapa komponen yang bekerja dalam sebuah sistem. Komponen-komponen bekerja sama satu sama lain untuk mencapai tujuan pendidikan. Input pendidikan adalah siswa sebelum mengikuti proses belajar mengajar. Dalam pendidikan siswa berinteraksi dengan komponen instrumental pendidikan seperti guru, materi, media, sarana dan metode mengajar, dalam pembelajaran siswa juga berinteraksi dengan lingkungan, baik fisik maupun sosial. Proses transformasi menghasilkan siswa yang telah berubah perilakunya setelah mengikuti pendidikan, perubahan prilaku tersebut disebut hasil belajar (Purwanto, 2011:20-21).

Hasil belajar termasuk salah satu komponen yang sangat penting dalam dunia pendidikan karena hasil belajar merupakan salah satu indikator atau tolak ukur untuk mengetahui tercapainya tujuan pengajaran. Berdasarkan data nilai ulangan harian kelas X semester 1 tahun ajaran 2012/2013 yang diberikan oleh guru bidang studi kimia SMA PGRI Indralaya diketahui hasil belajar siswa masih rendah. Kriteria ketuntasan minimal (KKM) pada mata pelajaran kimia kelas X di SMA PGRI Indralaya adalah sebesar 65. Pada hasil nilai ulangan harian pertama dengan materi sistem periodik unsur-unsur dan struktur atom diketahui sebesar 28,94\% siswa yang mencapai kriteria ketuntuasan minimal, hasil nilai ulangan harian kedua dengan materi ikatan kimia dan persamaan reaksi kimia diketahui sebesar $28,94 \%$ siswa yang mencapai kriteria ketuntasan minimal, dan pada 
ulangan harian ketiga dengan materi tata nama senyawa sederhana, hukum hukum dasar kimia dan konsep mol diketahui sebesar $23,68 \%$ siswa yang mencapai kriteria ketuntasan minimal. Dari ketiga hasil ulangan harian tersebut, maka rata-rata siswa yang mencapai kriteria ketuntasan minimal adalah sebesar $27,18 \%$.

Peneliti melakukan wawancara dan pengamatan terhadap RPP yang dibuat oleh guru pada tanggal 07 Februari 2013, diketahui bahwa proses pembelajaran kimia di kelas X SMA PGRI Indralaya didominasi dengan ekspositori. Selain itu, berdasarkan observasi dan pengalaman peneliti selama menjadi guru dalam kegiatan Praktik Pengalaman Lapangan (PPL) diketahui kondisi siswa selama proses pembelajaran berlangsung cenderung hanya mendengarkan penjelasan dari guru, kurangnya aktivitas mencatat maupun membaca. Ketika guru memberikan kesempatan kepada siswa untuk membaca buku paket pelajaran kimia, siswa terlihat tidak serius untuk membaca. Selain itu, siswa sangat jarang menyampaikan pendapat ataupun bertanya kepada guru ketika materi yang di pelajari tidak dimengerti. Interaksi atau komunikasi antar siswa belum juga belum berkembang, hal ini ditunjukan dengan kurangnya kegiatan berdiskusi ataupun bertanya kepada sesama teman ketika materi yang dipelajari belum dimengerti. Permasalahan tersebut berdampak pada kurangnya pemahaman siswa terhadap materi pelajaran kimia.

Salah satu upaya untuk meminimalisir masalah tersebut adalah dengan menggunakan strategi yang tepat dalam proses pembelajaran. Pemilihan strategi pembelajaran yang akan digunakan dalam proses pembelajaran harus berorientasi pada tujuan pembelajaran yang akan dicapai. Selain itu, harus disesuaikan dengan jenis materi, karakteristik peserta didik, serta kondisi di mana proses pembelajaran tersebut akan berlangsung. Ada berbagai metode dan teknik pembelajaran yang dapat digunakan oleh guru, tetapi tidak semuanya sama efektifnya mencapai tujuan pembelajaran. Untuk itu dibutuhkan aktivitas guru dalam memilih strategi pembelajaran (Uno dan Mohamad, 2011:26).

Salah satu strategi yang dapat dipilih adalah strategi pembelajaran thinktalk-write. Menurut Andriani (2010:207) think-talk-write adalah strategi yang memfasilitasi latihan berbahasa secara lisan dan tulisan. Strategi think-talk-write didasarkan pada pemahaman bahwa belajar adalah prilaku sosial. Strategi thinktalk-write medorong siswa untuk berfikir, berbicara dan kemudian menuliskan berkenaan dengan suatu topik.

Tahap pertama strategi think-talk-write adalah tahap think (berpikir) dimana ditahap ini siswa berpikir melalui membaca bahan bacaan yang disediakan, kemudian siswa dituntut untuk menyelesaikan masalah/soal yang disediakan di bahan tersebut dalam bentuk catatan secara mandiri (Andriani, 2010:207). Tahap kedua yaitu tahap talk (berbicara), talk dapat didefiniskan sebagai kemampuan untuk menyampaikan dengan lancar dalam mengekspresikan pikiran-pikiran, ide-ide, atau pemecahan masalah dalam bentuk kata-kata atau kalimat (Aqib dkk, 2011:33). Pada tahap talk ini, siswa dikelompokan secara heteogen dengan 3-5 siswa untuk berdiskusi. Tahap ketiga yaitu write (menulis), Andriani (2010:207) mengungkapkan bahwa pada tahap ini siswa diharapkan dapat menuliskan hasil yang dia dapat pada tahap pertama dan kedua. Pada tahap 
ini dapat dilihat sejauh mana pemahaman siswa terhadap materi yang dipelajari.

Penelitian dengan menggunakan strategi think-talk-write pernah dilakukan oleh Sulasmi (2009). Hasil penelitian menunjukan bahwa ada pengaruh yang signifikan penerapan strategi think-talk-write terhadap hasil belajar fisika siswa di kelas XI IPA 2 SMA Negeri 10 Palembang pada taraf $\alpha=5 \%$. Penelitian dengan menggunakan strategi think-talk-write juga dilakukan oleh Istiqomah (2009). Hasil penelitian menunjukan pelaksanaan pembelajaran matematika dengan strategi think-talk-write di kelas VIII-A SMPN 2 Bambanglipuro dapat meningkatkan peran aktif belajar siswa dalam pembelajaran matematika.

\section{PROSEDUR PENELITIAN}

Pada penelitian ini terdapat dua variabel yaitu variabel bebas dan variabel terikat. Variabel bebas dalam penelitian ini adalah strategi pembelajaran thinktalk-write dan yang menjadi variabel terikat adalah keaktifan dan hasil belajar kimia siswa. Penelitian ini dilakukan pada semester genap tahun ajaran 2012/2013 pada pokok bahasan hidrokarbon di kelas X SMA PGRI Indralaya yang berjumlah 27 siswa terdiri dari 17 laki-laki dan 10 perempuan

Penelitian ini adalah penelitian tindakan kelas yang dilakukan dalam 3 siklus. Satu siklus terdiri dari dua pertemuan. Setiap siklus terdiri atas 4 tahap kegiatan yaitu: perencanaan tindakan, pelaksanaan tindakan, observasi \& evaluasi, refleksi dalam setiap siklus. Pada siklus pertama mempelajari materi seyawa organik dan anorganik; cara identifikasi atom $\mathrm{C}$ dan $\mathrm{H}$; kekhasan atom karbon; atom $\mathrm{C}$ primer, atom $\mathrm{C}$ sekunder, atom $\mathrm{C}$ tersier, atom $\mathrm{C}$ kuartener; serta penggolongan hidrokarbon. Siklus kedua mempelajari materi tata nama senyawa hidrokarbon. Siklus ketiga mempelajari materi isomer dan reaksi senyawa hidrokarbon.

Teknik pengumpulan data yang digunakan dalam penelitian ini, yaitu dengan tes dan observasi. Tes hasil belajar merupakan tes penguasaan karena tes ini mengukur penguasaan siswa terhadap materi yang diajarkan oleh guru atau dipelajari oleh siswa (Purwanto, 2011:66). Pada penelitian ini tes dilakukan tiap akhir siklus. Observasi adalah cara menghimpun bahan-bahan keterangan (data) yang dilakukan dengan mengadakan pengamatan dan pencatatan secara sistematis terhadap fenomena-fenomena yang sedang dijadikan sasaran pengamatan (Sudijono, 2009:76).

Analisis data digunakan yaitu sebagai berikut:

\section{a. Analisa Data Hasil Belajar (Tes)}

Peningkatan hasil belajar siswa dapat dilihat dari persentase nilai ketuntasan siswa setiap siklusnya. Ketuntasan belajar siswa dapat dilihat dari sisi individual dan klasikal. Ketuntasan belajar individual tercapai bila memperoleh $\geq 65$ dan ketuntasan klasikal tercapai jika kelas tersebut $85 \%$ siswa yang memperoleh skor $\geq 65$.

Untuk menghitung persentase ketuntasan klasikal maka dapat digunakan rumus:

$$
\%=\frac{\sum \text { siswa yang tuntas belajar }}{\sum \text { Siswa }} \times 100 \%
$$

Sumber: Daryanto, 2011:192 


\section{b. Data Observasi}

Untuk melihat persentase keaktifan pada masing-masing deskriptor digunakan rumus:

$$
\%=\frac{\text { Skoraktivitas }}{\text { Skortotal aktivitas }} \times 100 \%
$$

Kateogori keatifan belajar siswa dapat dilihat pada Tabel 1 berikut:

Tabel 1. Kategori Keaktifan Belajar Siswa

\begin{tabular}{cc}
\hline Skor & Kategori Keaktifan Belajar Siswa \\
\hline $85-100 \%$ & Sangat baik \\
$65-84 \%$ & Baik \\
$55-64 \%$ & Cukup \\
$45-54 \%$ & Kurang \\
\hline
\end{tabular}

Sumber: Aqib dkk, 2011:160

Penelitian dikatakan berhasil jika keaktifan belajar siswa mencapai kategori baik dan hasil belajar siswa mencapai $85 \%$ siswa di kelas mendapatkan nilai $\geq 65$.

\section{HASIL}

a. Deskripsi Data Hasil Observasi Keaktifan Siswa Pada Siklus I, Siklus II dan Siklus III

Rekaptulasi keaktifan siswa dalam kelompok pada siklus I, siklus II, Siklus III dapat dilihat pada Tabel 2 berikut:

Tabel 2. Rekapitulasi Keaktifan Siswa Dalam Kelompok Setiap Pertemuan Pada Siklus I, Siklus II, Siklus III

\begin{tabular}{l|c|c|c|c|c|c|c}
\hline \multirow{2}{*}{ No. } & \multirow{6}{*}{ Kelompok } & \multicolumn{6}{|c}{ Keaktifan Siswa Dalam Kelompok (\%) } \\
\cline { 2 - 8 } & & \multicolumn{2}{|c|}{ Siklus 1 } & \multicolumn{2}{c}{ Siklus II } & \multicolumn{2}{c}{ Siklus III } \\
\cline { 2 - 8 } & & 1 & II & I & II & I & II \\
\hline 1. & I & 50,00 & 53,85 & 76,92 & 80,77 & 80,77 & 86,54 \\
\hline $\mathbf{2 .}$ & II & 48,72 & 53,85 & 57,69 & 69,23 & 80,77 & 86,54 \\
\hline $\mathbf{3 .}$ & III & 38,46 & 55,38 & 55,38 & 58,46 & 86,54 & 88,46 \\
\hline $\mathbf{4 .}$ & IV & 69,23 & 57,77 & 76,92 & 69,23 & 79,49 & 82,05 \\
\hline $\mathbf{5 .}$ & V & 50,00 & 48,72 & 56,41 & 55,77 & 78,46 & 82,69 \\
\hline 6. & VI & 40,38 & 42,31 & 53,85 & 64,10 & 76,92 & 80,77 \\
\hline $\begin{array}{l}\text { \% Rata-rata keaktifan siswa } \\
\text { dalam kelompok }\end{array}$ & 49,47 & 51,65 & 62,86 & 66,26 & 80,49 & 84,51 \\
\hline $\begin{array}{l}\text { \% Rata-rata keaktifan siswa } \\
\text { dalam kelompok persiklus }\end{array}$ & \multicolumn{2}{|c|}{$\mathbf{5 0 , 5 6}$} & \multicolumn{3}{|c|}{$\mathbf{6 4 , 6 6}$} & \multicolumn{2}{|c|}{$\mathbf{8 2 , 5 0}$} \\
\hline
\end{tabular}

Berdasarkan Tabel 2, persentase keaktifan belajar siswa mengalami peningkatan dari siklus I sampai dengan siklus III. 
b. Hasil Belajar Siswa Sebelum Diberikan Tindakan ( $\left.\mathbf{T}_{0}\right)$, Siklus I ( $\left.\mathbf{T}_{1}\right)$, Siklus II $\left(\mathbf{T}_{2}\right)$, Siklus III $\left(\mathbf{T}_{3}\right)$

Data tes sebelum tindakan $\left(\mathrm{T}_{0}\right)$ diambil dari nilai ulangan siswa pada pokok bahasan reaksi oksidasi dan reduksi. $\left(\mathrm{T}_{1}\right)$ diambil dari hasil tes siklus satu, $\left(\mathrm{T}_{2}\right)$ diambil dari hasil tes siklus dua dan $\left(\mathrm{T}_{3}\right)$ diambil dari hasil tes siklus tiga. Rekaptulasi hasil belajar siswa $\left(\mathrm{T}_{0}\right),\left(\mathrm{T}_{1}\right),\left(\mathrm{T}_{2}\right)$ dan $\left(\mathrm{T}_{3}\right)$ terdapat pada Tabel 3. Sedangkan diagram batang persentase rata-rata keaktifan siswa, rata-rata hasil belajar dan persentase ketuntasan klasikal pada siklus I, siklus II dan siklus III pada Gambar 1 berikut:

Tabel 3. Rekaptulasi hasil belajar siswa

\begin{tabular}{cccccc}
\hline Siklus & $\begin{array}{c}\text { Jumlah } \\
\text { siswa }\end{array}$ & $\begin{array}{c}\text { Jumlah siswa yang } \\
\text { tidak tuntas (nilai 0- } \\
\text { 64) }\end{array}$ & $\begin{array}{c}\text { Jumlah siswa } \\
\text { yang tuntas } \\
\text { (nilai 65-100) }\end{array}$ & $\begin{array}{c}\text { Rata-rata } \\
\text { hasil } \\
\text { belajar }\end{array}$ & $\begin{array}{c}\text { Persentase } \\
\text { ketuntasan } \\
\text { klasikal }\end{array}$ \\
\hline $\mathbf{T}_{\mathbf{0}}$ & 23 & 16 & 8 & 54,26 & $34,78 \%$ \\
\hline $\mathbf{T}_{\mathbf{1}}$ & 23 & 11 & 12 & 59,48 & $52,17 \%$ \\
\hline $\mathbf{T}_{\mathbf{2}}$ & 21 & 7 & 14 & 67,62 & $66,67 \%$ \\
\hline $\mathbf{T}_{3}$ & 23 & 3 & 20 & 75,08 & $86,95 \%$ \\
\hline
\end{tabular}

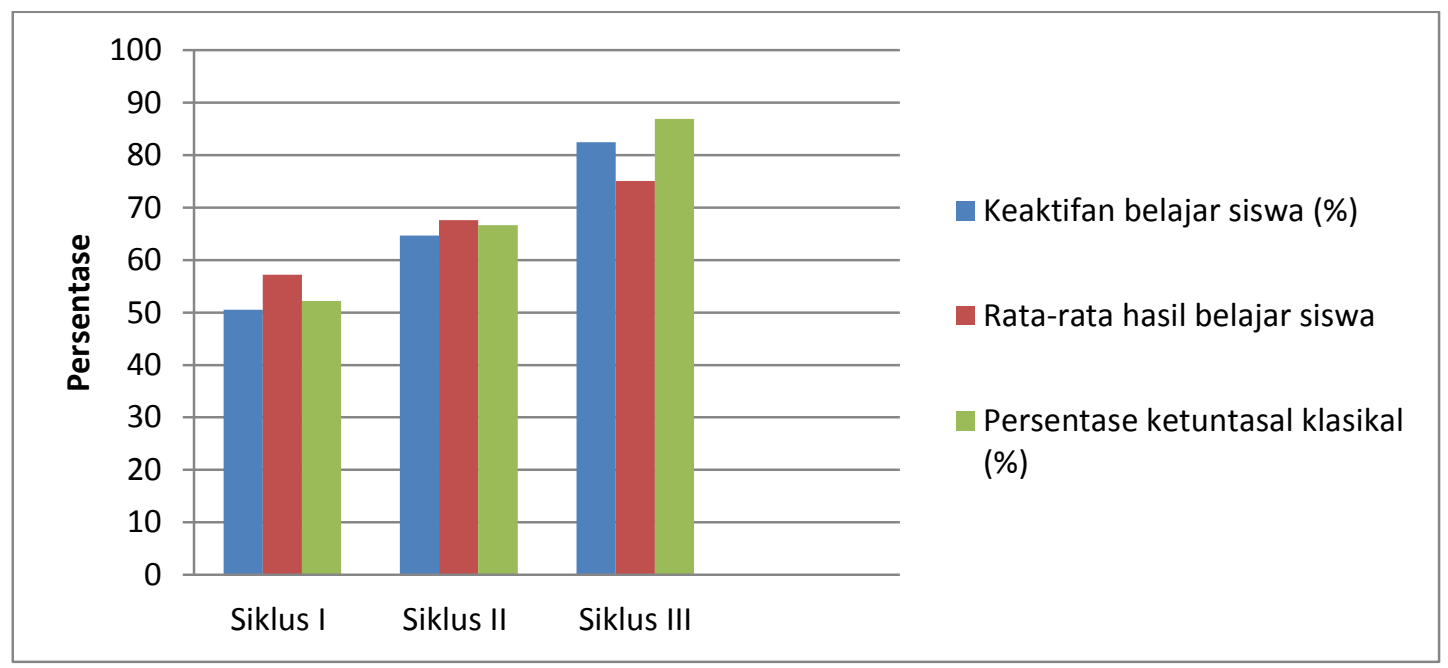

Gambar 1. Diagram Batang Persentase Keaktifan, Rata-rata Hasil Belajar dan Ketuntasan Klasikal

\section{PEMBAHASAN}

Berdasarkan data tes hasil belajar sebelum diberi perlakuan $\left(\mathrm{T}_{0}\right)$ yang diambil dari nilai ulangan siswa pada pokok bahasan sebelumnya, yaitu reaksi oksidasi \& reduksi, dari 23 siswa ada 16 siswa yang mendapatkan nilai < 65, dan 8 orang siswa yang mendapatkan nilai $\geq 65$, sehingga persentase ketuntasan hasil 
belajar $\mathrm{T}_{0}$ adalah $34,78 \%$. Rendahnya ketuntasan hasil belajar terjadi karena proses pembelajaran belum menerapkan strategi pembelajaran yang dapat melibatkan siswa secara langsung dan membantu siswa memahami konsep materi.

Pada siklus I, guru membimbing siswa dan menjelaskan materi pelajaran melalui lembar kerja siswa, guru menugaskan kepada setiap siswa untuk memikirkan penyelesaian masalah/soal yang ada di lembar kerja dan menuangkan gagasan/ide terhadap permasalahan atau pertanyaan yang ada di lembar kerja tersebut dalam bentuk catatan kecil (think). Kemudian guru mengkondisikan siswa dalam kelompok-kelompok kecil (3-5 orang siswa) untuk berdiskusi mengenai apa yang telah dia dapatkan pada tahap think. Guru dan observer memonitor bagaimana jalannya diskusi. Setelah proses berdiskusi selesai, guru meminta siswa kembali ke tempat duduknya masing-masing untuk menuliskan hasil kontruksi dari pemikirannya ditahap think dan hasil diskusi pada tahap talk dan menjawab pertanyaan secara individual (write). Setelah itu guru meminta siswa mempresentasikan hasil pekerjaannya. Persentase keaktifan siswa yang diperoleh dari analisis lembar observasi pada siklus I yaitu 50,56\%. Berdasarkan hasil tes akhir siklus diperoleh peningkatan terhadap ketuntasan $\mathrm{T}_{0}$ yaitu $34,78 \%$ menjadi $52,17 \%$ dan juga terjadi peningkatan rata-rata hasil belajar dari 54,26 menjadi 59,48. Peningkatan ini disebabkan karena keterlibatan siswa secara langsung dalam proses pembelajaran melalui strategi think-talk-write.

Pada siklus 1 ini terjadi penurunan persentase keaktifan pada kelompok IV dari 69,23\% ke 57,57\%. Hal itu disebabkan karena salah satu anggota kelompok mereka yaitu Wildan yang pada pertemuan pertama tidak hadir. Wildan terlihat belum mengerti akan tugas yang harus dilakukannya pada pertemuan kedua, dia tidak membuat catatan terhadap penyelesaian masalah yang ada di lembar kerja siswa. Pada saat diskusi dia terlihat pasif, dia hanya mencotek pekerjaan dari teman satu kelompoknya. Sedangkan untuk kelompok $\mathrm{V}$ terjadi penurunan persentase keaktifan dari 50,00\% ke 48,72\% dikarenakan Desi Auliah yang pada pertemuan sebelumnya juga tidak hadir belum mereasa nyaman berada dalam kelompok dikarenakan dia adalah satu-satunya anggota kelompok yang berjenis kelamin perempuan. Pada saat diskusi, Desi tidak terlibat aktif dalam diskusi melainkan main handphone.

Dari hasil tes, nilai ketuntasan siswa pada siklus 1 ini masih jauh dari ketuntasan klasikal yaitu $85 \%$. Hal ini disebabkan terdapat kelemahan-kelemahan pada proses pembelajaran. Siswa belum terbiasa dengan pembelajaran menggunakan strategi think-talk-write. Siswa masih malu bertanya kepada guru ketika materi pelajaran tidak dimengerti. Proses diskusi juga belum berjalan dengan baik, diskusi hanya didominasi oleh beberapa siswa saja, siswa yang belum mengerti hanya diam dan mencotek pekerjaan temannya. Hal tersebut menyebabkan siswa kesulitan pada tahap write, ketika di minta menuliskan hasil kontruksi dari pemikirannya dari tahap think dan talk, siswa tidak percaya diri masih bertanya ataupun sekedar menyamakan jawaban dengan temannya. Ketidakpercayaan diri tersebut berdampak pada ketidakberanian siswa dalam mempresentasikan hasil pekerjaanya. Oleh karena itu perlu adanya perbaikan dalam proses pembelajaran selanjutnya.

Pada siklus II ini merupakan perbaikan dari siklus I. Persentase keaktifan kelompok pada siklus II mengalami peningkatan dari siklus I yaitu 50,56\% menjadi $64,66 \%$. Namun tidak semua kelompok yang mengalami peningkatan 
persentase keaktifan. Kelompok IV mengalami penurunan persentase keaktifan dari $76,92 \%$ ke $69,23 \%$ dan kelompok $\mathrm{V}$ juga mengalami penurunan persentase keaktifan dari 56,41\% ke 55,77\%. Hal tersebut dikarenakan Dicky Chandra anggota dari kelompok IV dan Allian Alkatani anggota dari kelompok V terlihat tidak bersemangat ketika mengikuti pelajaran, ketika guru bertanya mengenai kesehatan mereka, mereka menjawab sedang kurang sehat. Faktor kesehatan ini mempengaruhi keaktifan mereka dalam belajar, mereka terlihat tidak semangat dalam kegiatan diskusi maupun kegiatan mempresentasikan jawaban mereka. Faktor ketidaksehatan berdampak juga terhadap hasil belajar siswa, hal ini ditunjukan data hasil test siklus siswa yang menunjukan penurunan nilai yang diperoleh Dicky Chandra yaitu pada siklus 1 mendapatkan nilai 95 menjadi 85 pada siklus II sedangkan nilai Allian Alkatani pada siklus 1 yaitu 65 menurun menjadi 60 pada siklus II. Hal tersebut sesuai dengan pendapat yang dikemukakan oleh Uno dan Mohamad (2011:198) bahwa kondisi kesehatan tubuh secara umum mempengaruhi semangat dan konsentrasi belajar siswa dalam mengikuti pelajaran. Tubuh yang lemah dapat menurunkan kualitas kognitif siswa, sehingga materi yang dipelajari sulit dicerna.

Ketuntasan hasil belajar siswa meningkat dari siklus I yaitu dari 52,17\% menjadi $66,67 \%$. Rata-rata hasil belajar juga meningkat dari 59,48 menjadi 67,62 Peningkatan hasil belajar tersebut disebabkan karena siswa sudah mulai terbiasa belajar menggunakan strategi think-talk-write sehingga siswa lebih aktif dari pada pertemuan sebelumnya. Pada siklus II ini, guru lebih memimbing siswa dalam berdiskusi, guru mendatangi kesetiap kelompok, memberi pengarahan agar siswa lebih aktif dalam berdiskusi. Interaksi antar siswa dalam diskusi sudah lebih baik dibandingkan dengan siklus I, namun masih ada siswa yang belum terlibat aktif dalam diskusi. Siswa sudah terlihat berani mempresentasikan hasil pekerjaannya, namun siswa yang berani mempresentasikan pekerjaannya tersebut hanya didominasi oleh siswa-siswa tertentu. Oleh karena itu masih perlunya perbaikan tindakan untuk siklus selanjutnya, yaitu guru harus lebih memotivasi siswa agar terlibat aktif dalam proses pembelajaran.

Pada siklus III, siswa mempelajari materi isomer dan persamaan reaksi. Siklus III ini merupakan perbaikan dari kelemahan-kelemahan yang ada pada siklus II. Persentase keaktifan pada siklus III yaitu sebesar $82,50 \%$. Persentase keaktifan tersebut meningkat dari siklus I dan siklus II. Rata-rata hasil belajar siswa sebesar 75,08. Ketuntasan hasil belajar pada siklus III yaitu 86,95\%. Ketuntasan hasil belajar pada siklus III ini sudah mencapai ketuntasan klasikal yaitu $85 \%$.

Pada siklus III ini siswa sudah terbiasa dengan belajar menggunakan strategi think-talk-write. Siswa terlihat lebih aktif dibandingkan dengan siklus I dan siklus II. Pada siklus III ini, guru lebih meningkatkan motivasi siswa agar terlibat aktif pada proses pembelajaran dengan memberikan reward berupa pena kepada siswa yang berani bertanya, menjawab pertanyaan dari guru. Proses diskusi sudah berajalan efektif, guru dan observer memonitoring proses jalannya diskusi. Siswa sudah berani bertanya kepada guru dan observer ketika ada kendala pada saat berdiskusi. Siswa yang kurang paham bertanya kepada teman satu kelompoknya, dan siswa yang sudah mengerti menjelaskan kepada temannya 
tersebut. Hal tersebut dapat meningkatkan pemahaman siswa terhadap materi pelajaran. Sesuai dengan pendapat yang dikemukakan oleh Daryanto dan Rajardjo (2012:124-125) bahwa bertanya mengenai hal yang belum jelas merupakan salah satu cara untuk dapat mengerti bahan pelajaran yang belum dimengerti. Malu bertanya akan menghambat penguasaan bahan yang akan diterima pada pertemuan selanjutnya, jadi bertanyalah mengenai hal-hal yang belum jelas sehingga bahan pelajaran dapat dikuasi dengan baik.

Pada saat mempresentasikan pekerjaannya, siswa terlihat antusias mengangkat tangan untuk mempresentasikan hasil dari pekerjaannya. Pemberian reward berupa pena ternyata efektif membuat siswa terlibat aktif dalam proses pembelajaran.

Strategi think-talk-write ini dapat meningkatkan keaktifan dan hasil belajar kimia siswa hal ini sesuai dengan penelitian sebelumnya oleh Istiqomah (2009) menunjukan bahwa pembelajaran matematika dengan strategi think-talk-write dalam upaya meningkatkan peran aktif dan prestasi belajar siswa kelas VIII SMP Negeri 2 Bambanglipuro Bantul dapat mencapai tujuan.

\section{KESIMPULAN DAN SARAN}

\section{Kesimpulan}

Berdasarkan hasil penelitian dan pembahasan yang telah diuraikan, dapat disimpulkan bahwa melalui strategi pembelajaran think-talk-write hasil belajar kimia siswa kelas X SMA PGRI Indralaya dapat meningkat. Pada siklus I rata-rata hasil belajar yaitu 59,48 dengan ketuntasan klasikal sebesar 52,17\%. Pada siklus II rata-rata hasil belajar yaitu 67,62 dengan ketuntasan klasikal sebesar 66,67\%. Pada siklus III rata-rata hasil belajar siswa yaitu 75,08 dengan ketuntasan klasikal sebesar $86,95 \%$. Siswa kelas X dinyatakan telah tuntas belajar secara klasikal pada siklus III.

Selain itu, penerapan strategi think-talk-write dalam pembelajaran kimia di SMA PGRI Indralaya juga memberikan dampak positif terhadap keaktifan siswa dan mengalami peningkatan dari siklus sebelumnya. Persentase rata-rata keaktifan pada siklus I adalah sebesar 50,56\%, persentase rata-rata siklus II adalah sebesar $64,66 \%$, persentase rata-rata siklus III adalah sebesar $82,50 \%$.

\section{Saran}

Berdasarkan penelitian yang telah dilakukan, maka peneliti memberikan saran kepada guru kimia maupun guru bidang studi lainnya dalam proses belajar mengajar di kelas dapat menerapkan strategi think-talk-write sebagai salah satu alternatif untuk meningkatkan keaktifan dan hasil belajar siswa. Bagi sekolah, diharapkan dapat menggunakan hasil penelitian ini sebagai masukan dalam upaya meningkatkan kualitas pembelajaran. Bagi peneliti lain, disarankan agar dapat menggunakan hasil penelitian ini sebagai acuan untuk mengembangkan pelajaran yang dapat meningkatkan keaktifan dan hasil belajar siswa menggunakan strategi think-talk-write. 


\section{DAFTAR RUJUKAN}

Andriani, M. (2010). Pengembangan Perangkat Pembelajaran Matematika Berbasis Strategi Think-Talk-Write Untuk Mengingkatkan Kemampuan Komunikasi Dan Pemecahan Masalah Matematika Siswa Madrasah Ibtidaiyah. Makalah disampaikan dalam Seminar dan Rapat Tahunan Bidang Ilmu MIPA Badan Kerjasama PTN Wilayah Barat (SEMIRATA BKS-PTN B) Tahun 2010, pada tanggal 10-11 Mei 2010 di Universitas Riau.

Aqib, Zainal., Maftuh, M., Sujak., Kawentar. (2008). Penelitian Tindakan Kelas Untuk Guru SMP, SMA, SMK. Bandung: Yrama Widya.

Daryanto. (2011). Penelitian Tindakan Kelas dan Penelitian Tindakan Sekolah Beserta Contoh-contohnya. Yogyakarta: Gava Media.

Daryanto dan Rahardjo, M. (2012). Model Pembelajaran Inovatif. Yogyakarta: Gava media.

Istiqomah, A. N. (2009). Pembelajaran Matematika Dengan Strategi Think-TalkWrite (TTW) Dalam Upaya Meningkatkan Peran Aktif dan Prestasi Belajar Siswa Kelas VIII SMP Negeri 2 Bambanglipuro Bantul. Skripsi. Yogyakarta: Universitas Islam Negeri Sunan Kalijaga. http://digilib.uinsuka.ac.id/3854/. Diakses tanggal 1 Mei 2013.

Purwanto. (2011). Evaluasi Hasil Belajar. Yogyakarta: Pustaka Pelajar.

Sudijono, A. (2011). Pengantar Evaluasi Pendidikan. Jakarta: Raja Grafindo Persada.

Sulasmi. (2009). Pengaruh Penerapan Strategi Pembelajaran Think-Talk-Write (TTW) Terhadap Hasil Belajar Fisika Siswa Di Kelas XI SMA Negeri 10 Palembang. Skripsi. Indralaya: FKIP Universitas Sriwijaya.

Uno, H. B dan Mohamad, N. (2001). Belajar dengan pendekatan PAILKEM. Jakarta: Bumi Askara. 